\title{
Morphosyntactic influence of spanish on english as a foreign language in high school students
}

\section{Influencia morfosintáctica del español en inglés como lengua extranjera en estudiantes de secundaria}

DOI: $10.46932 / s f j d v 2 n 5-094$

Received in: Oct 1st, 2021

Accepted in: Dec 30th, 2021

\section{Willian Patricio García Padilla}

Magister in English Language and Applied Linguistics - Universidad de Cuenca, Ecuador

Unidad Educativa "Miguel Moreno Ordóñez," Cuenca, Ecuador

010111, Cuenca, Ecuador

E-mail: willy35612@hotmail.com

Yola Indaura Chica Cárdenas

Magister in English Language and Applied Linguistics - Universidad de Cuenca, Ecuador

Master in Curriculum and Instruction ESL - Kansas State University

Universidad de Cuenca

010114, Cuenca, Ecuador

E-mail: yola.chica@ ucuenca.edu.ec

\begin{abstract}
When learning a foreign language, the mother tongue (L1) influences the learning process either to enhance or to hinder it. The purpose of this study was to ascertain the most common errors high school students make due to the Spanish morphosyntactic interference when developing the English writing skill, to determine the factors that caused those errors and to propose some suggestions to overcome them. The participants of the study were 32 students of an Ecuadorian public high school. A quantitative and qualitative study was carried out; data collection instruments included a pre and a post-test as well as a questionnaire for students and teachers. Four morphosyntactic errors were identified: word order, negation, pluralization, and subject omission. After the intervention, it was determined that to overcome these errors, school teachers should focus on practicing more writing activities with their students in class and on motivating learners to do English tasks at home.
\end{abstract}

Keywords: learning, cross-linguistic influence, morphosyntax, erros.

\section{RESUMEN}

$\mathrm{Al}$ aprender una lengua extranjera, la lengua materna (L1) influye en el proceso de aprendizaje para potenciar o dificultarlo. El propósito de este estudio fue conocer los errores más comunes que cometen los estudiantes de secundaria debido a la interferencia morfosintáctica del español en el aprendizaje de la habilidad de escritura en inglés, para determinar los factores que causaron esos errores y proponer algunas soluciones para superarlos. Los participantes del estudio fueron 32 estudiantes de una escuela secundaria pública ecuatoriana. Se realizó un estudio cuantitativo y cualitativo; los instrumentos de recolección de datos incluyeron un pre y post-test, y un cuestionario para estudiantes y docentes. Se identificaron cuatro errores morfosintácticos: orden de palabras, negación, pluralización y omisión de sujeto. Luego de la intervención, se determinó que para superar esos errores, los profesores deberían enfocarse en practicar 
más actividades de escritura con sus estudiantes en clase y en motivar a los estudiantes a hacer tareas de inglés en casa.

Palabras clave: aprendizaje, influencia translingüística, morfosintaxis, errores.

\section{INTRODUCTION}

Human beings have a first language or mother tongue (L1) as a general tool of communication; in addition to the L1, they can learn or acquire a second language (L2). In this process, the L1 influences either positively or negatively, what is generally called positive and negative transfer (Xiangui, 2005). When the L1 and L2 share some similarities, the learning process becomes easier, but when there are major differences, the process is quite difficult, leading to students making errors, especially morphosyntactic ones. Kester and Gorman (2008) state that the cross-linguistic influence that occurs in the learning process causes these errors.

This paper addresses a difficulty that is strongly related to native language interference in the English learning process: morphosyntax, which refers to the way words are grammatically formed and ordered to form phrases, clauses, and sentences (Isakson \& Spyridakis, 2003). The problem that Spanish native students face, who in this case are finishing high-school in an Ecuadorian public institution, has to do with the development of their English writing skill. Our own experience as English teachers has allowed us to notice that high school students in the third year of Bachillerato (the last year) continue to make errors when writing, even though these students have been studying English as a foreign language for six or more years. Mostly, these errors are produced because they transfer Spanish structures when writing in the L2. Based on this context, the main goal of this research is to ascertain how Spanish morphosyntax affects high school students' English writing skills in an Ecuadorian public institution. The study addresses the following research questions:

- RQ1. What are the most common English morphosyntactic errors produced by students in writing?

- RQ2. What are the factors that induce students to make these errors?

- RQ3. What kinds of activities can help high school students avoid the interference of Spanish morphosyntax in English?

This work includes, firstly, the background research; secondly, it presents the methodology, results and analysis, and finally some conclusions.

\section{BACKGROUND RESEARCH}

To answer this paper's research questions, we focus on three areas: first, it is necessary to review the terms Morphology, Syntax, and Error Analysis; second, it is important to understand what cross- 
linguistic influence is; and third, a contrastive analysis is carried out to determine the most common errors they produce.

\subsection{MORPHOLOGY, SYNTAX, AND ERROR ANALYSIS}

Lieber (2009) defines Morphology as the study of word formation; this study includes "the ways new words are coined in the languages of the world, and the way forms of words are varied depending on how they're used in sentences" (p. 2).

On the other hand, Syntax traditionally refers to the branch of grammar dealing with the ways in which words are arranged to show connections of meaning within sentences (Matthews as cited in Van Valin, 2001). L2 learners need to know the syntactic part of the language to construct coherent sentences. Thus, they have to apply a set of rules and principles to acquire communicative competence to construct accepted sentences as the well-formed grammatical structures similar to those by native speakers (Sells \& Kim, 2007).

Error Analysis is a procedure used by both teachers and researchers to collect samples of a learner's language, identify the most prominent errors, describe these errors, classify them according to their nature and causes, and evaluate their seriousness (Heydari \& Bagheri, 2012). This kind of analysis has been applied to achieve the goals of this investigation. It is important to be aware that errors are part of the learning process (Kthupi, 2015), and by understanding students' errors, teachers might apply the necessary strategies and provide proper feedback to help the learner use the target language properly (Heydari \& Bagheri, 2012).

\subsection{CROSS-LINGUISTIC INFLUENCE AND INTERLANGUAGE}

Jarvis and Pavlenko (2008) assert that cross linguistic influence (CLI) refers to the influence the knowledge of one language has on the individual's learning of another language. This means that L2 learners use some clues from their L1 to express something in the L2 because they have not yet learned its clue system (Kester \& Gorman, 2008). In this case, positive transfer occurs; for instance, in the case of English and Spanish, a considerable percentage of English words are cognates with Spanish ones. For example,

$\begin{array}{ll}\text { English } & \text { Spanish } \\ \text { radio } & \text { radio } \\ \text { hospital } & \text { hospital } \\ \text { sofa } & \text { sofá }\end{array}$


Another aspect of positive transfer is the morphological patterns that exist between English and Spanish words. These patterns relate to the endings of some words, for instance: in nouns -ence / -encia: conference, conferencia; in adjectives -ous/-oso: famous, famoso; in verbs - ify/-ificar: clarify, clarificar; in adverbs -ly/ -mente: actually, realmente (Lapo, 2008).

On the other hand, in the case of the negative transfer effect, Kestern and Gorman (2008) state that native Spanish speakers tend to use some morphosyntactic Spanish cues in English, which produce morphosyntactic errors in the target language. Some of the most common errors are word order, negation, pluralization (Kestern \& Gorman, 2008; Coello \& Coello, 2009), subject omission (Kestern \& Gorman, 2008), definite and indefinite articles, prepositions, and possessive pronouns (Coello \& Coello, 2009). These errors can prevail in the learner until they are fossilized, meaning that learners develop a fairly fixed language that does not match the target language and from which they cannot progress any further (Yule, 2010).

In addition, in the language learning process, negative transfer is also involved in interlanguage. According to Tarone (2006), interlanguage is a separate linguistic system evidenced when a L2 learner wants to express meaning in the target language. This means there is an intermediate stage between a learner's L1 and L2 in which the learner uses both linguistic systems to express something in the L2 (Luna, 2010).

\subsection{CONTRASTIVE GRAMMAR}

Contrastive Grammar refers to the result of contrastive studies undertaken to a bilingual grammar, emphasizing the differences across languages (Sanchez, 2015). Contrastive Grammar has been used to explain the following errors made by the participants in this study: word order, negation, pluralization, and subject omission.

1. Through contrastive analysis, it is possible to notice the differences in word order in English and Spanish. The English language has a strict word order, and most English structures adopt the SubjectVerb-Object (SVO) formula. Similarly, the order of objects, complements, and modifiers follows specific rules. Conversely, William (2003) states that in Spanish sentences have less restricted word order than in English. Taboada (1995) also mentions that Spanish has a pragmatically-controlled flexible word order but which inclines toward the natural process of SVO; there is an alternance of SV and VS. When referring to word order in non-sentence construction, Taboada (1995) affirms that the first position is important in the progress of information in English, but in Spanish, the order of the elements is not the same. For instance, in Spanish, deictics and possessives come first and newer information comes last. Therefore, the position of the words determines the development of the information from old to new or from general to specific. Indeed, although English and Spanish have their own word order, they share similar 
characteristics; however, syntactic rules are different. This causes students to make some errors when writing in the foreign language

2. Negation is the second most common error that English learners make in the learning process. Regarding syntax, in English there are three types of negation: verbal and non-verbal, analytic and synthetic, and double negation, which is considered the most troublesome by Spanish native speakers learning English (Zamora, 2015).

In English Verbal negation, the verb is linked to the negation part and acts as the head of the clause, and Non-verbal negation deals with complements of the verb that express negation instead of the verb (Zamora, 2015). In analytic negation, words to negate appear only when the sentence needs to be negated. This is the case of the adverbs not and no. On the contrary, in the case of synthetic negation, there are some words that express not only a negation but also a syntactic function, such as nobody, few, hardly (Zamora, 2015).

Related to double negation, some languages accept the use of negative concord. This means that two or more negatives are used in only one sentence without changing the meaning (Zamora, 2015). However, some languages, such as English, do not accept double negatives since it might cause a positive meaning; for example, if we analyze carefully the example "it is not undone," the meaning is positive; but if you say "it is not done," the meaning is negative.

Additionally, it is important to indicate that double negative confusion persists in Spanish students of English because of the placement of the adverb no, which has a specific place to have a correct grammatical structure; however, in Spanish the adverb no can be placed in different parts of the sentence, forming double negation (Zamora, 2015).

Zamora (2015) states that in Spanish there are two types of negation: grammatical and lexical. Grammatical negation can be full grammatical negation, partial negation, and finally, negation of a subordinate clause, which affects a specific part of the sentence. For example:

\section{No está lloviendo por el centro de la ciudad. full grammatical negation \\ Canta, pero no canciones de rock. \\ Me dijo que no contara su secreto. \\ partial negation \\ negation of a subordinate clause}

Lexical negation implies that there are some words considered as negatives and affects just one part of the sentence, for instance, pronouns such as nadie and ningún.

Nadie te ayudará con tu deber.

Ningún estudiante aplaudió al artista. 
Double negation, containing two different negation markers, occurs and is accepted in Spanish only when one of the negative forms is the adverb no and the other one is used to emphasize the negation. Nadie, in English nobody and jamás, in English never, are negative markers in Spanish. For example:

No participará nadie en las elecciones.

No volveré jamás.

3. Most Spanish speakers learning English apply their native language's plural rules to express something in plural in the L2. For example, to express English plurality, they add only the suffix -s or es as most of the plurals are made in Spanish. Similarly, in English, the majority of plurals are expressed by the addition of the inflectional morpheme -s or -es, as in Spanish. In this case, both Spanish and English, share a similar morphological structure to indicate a certain meaning, which is positive transfer (Minkkinen, 2015).

However, there are other morphemes that make English plurals different from Spanish ones, that differ from the norm and are irregular. This refers to nouns that change the form in the plural (Minkkinen, 2015), as the examples show

Irregular plural formation of nouns

$\begin{array}{lr}\text { Singular } & \text { Plural } \\ \text { Wolf } & \text { wolves } \\ \text { Man } & \text { men } \\ \text { Child } & \text { children }\end{array}$

Additionally, there are some words, such as fish, deer, sheep, that keep the same form to express singular and plural; thus, they do not have plural markers and are known as zero plurals (Minkkinen, 2015).

As mentioned earlier, the Spanish language also uses the inflections "-s" and "-es," but in this case, these inflections are used differently. Referring to the "-s" ending, it is used only when a Spanish word ends in a vowel: casa - casas; on the contrary, the "-es" ending is used when a word ends in a consonant: papel - papeles. However, there are two exceptions; regarding the first one, Spanish plural forms are formed by adding the morpheme "-es” after the accented vowels "í": capuli - capulies or "ú”: bambú bambúes. About the second exception, nouns that end in the consonant "-s" remain in singular, except when the final consonant "-s" is preceded by an accented vowel, for example: el martes - los martes; el autobús - los autobuses (Minkkinen, 2015). 
Another important difference between English and Spanish is that in Spanish all adjectives defining the head noun must agree with the noun in terms of number and gender (Minkkinen, 2015); however, the use of plurals with adjectives is not allowed in English. For example,

\section{Spanish}

Chicas bonitas

Grandes construcciones

\section{English}

*beautifuls girls - beautiful girls

*bigs buildings - big buildings

Beautifuls girls and bigs buildings are ungrammatical constructions in English. Thus, L2 learners use English plurals incorrectly due to the L1's (Spanish) interference. In other words, sometimes students think that nouns that are not marked with the morpheme "-s," are interpreted as singular, and if they are marked with "-s," they are interpreted as plural (Campos, 2011).

4. Shepherd (2011) states that subject omission means to break the rule that states that we have to include either a noun or pronoun as a subject in all the sentences in English. The use of null subjects or subject omission in Spanish is completely appropriate, but in English, it is considered ungrammatical (Mujsinovic, 2015). For example:

Tom y Mary son amigos. Siempre juegan con un balón.

Tom and Mary are friends. They always play with a ball.

Both examples convey the same meaning; however, in the second set of sentences in Spanish, the subject is omitted since it is understood that it refers to Tom and Mary. On the contrary, in the second sentence, speakers must use a subject (in this case a pronoun) because it is grammatically obligatory in non-imperative English sentences.

\section{METHODOLOGY}

This exploratory mixed-methods research involved a quantitative and qualitative study to help explain the questions presented herein. As Cresswell and Garrett (2008) state, the fact that researchers use both approaches together strengthens the understanding of research problems.

\subsection{PARTICIPANTS}

The participants of the research were 32 students (16 male and 16 female), between the ages of 16 to 20 years old, of a public high school in Cuenca, Ecuador. These students were in the last year of secondary school, and their English learning process was based on the new curriculum established by the 
country's Ministry of Education, which focuses on the CEFR (Common European Framework of Reference for Languages). In effect, this demands that students of the third year of bachillerato (last year of secondary education) reach at least a B1 English level proficiency.

It is worth mentioning that Ecuadorian students do not generally attain the level established in the curriculum since the standards are high, the number of hours to teach English is not sufficient, and the curriculum is not appropriate for the standards proposed (Souriyavongsa et al., 2013). Thus, learners have a low English level proficiency.

\subsection{QUANTITATIVE AND QUALITATIVE DATA COLLECTION}

The study began after receiving the necessary permissions from school authorities, the parents' authorization for underage students through a signed consent form, as well as the authorization from students over the age of eighteen. Data collection included both qualitative as well as qualitative instruments.

Quantitative data collection took place first. A pre-test and a post-test were applied after being piloted with similar students. The pre-test, based on Martinez (2011), was applied to know what morphosyntactic errors were the most common in the 32 students in this research. After the pre-test, the students' English instructor carried out a 32-hour intervention in order to improve the areas where students showed problems. At the end of the intervention, the post-test was applied to know whether or not the students had corrected the morphosyntactic errors found in the pre-test. This study does not include an analysis of the intervention itself.

Regarding the qualitative method, two questionnaires were applied during the intervention. The first one, whose goal was to determine the possible reasons of the English morphosyntactic errors, was for the students, who were taken as a focus group. Codes were assigned to all participating students to maintain anonymity; in that way, all information was identified and linked accurately anonymously. The second questionnaire was for teachers; its goal was to determine if teachers were aware of the morphosyntactic errors students make when writing, to know which errors they identify, and what strategies they use to help students overcome those errors. This questionnaire was applied to thirteen English teachers. These teachers, who volunteered to participate in this study, taught English to students of Bachillerato. Three worked at the same institution where the study took place and the ten others worked in other public high schools of the city. Finally, each of these tools had an introductory paragraph written in Spanish giving information about the study to avoid misunderstandings by teachers and students.

Concerning the intervention, the activities included were meant to help students overcome the most common errors found in the pre- test - word order, negation, pluralization, and subject omission. 
These activities included exercises related to grammar, reading, and writing that students worked on in class and at home; in addition, the teacher reinforced the students' work by providing continuous feedback.

\section{RESULTS}

\subsection{ANALYSIS AND DISCUSSION}

The data collected was analyzed to answer the research questions proposed at the beginning of this study. The quantitative data from the pre and post-tests that had eight multiple choice items for assessing each error, 32 answers in total, made it possible to recognize and classify the most and least common morphosyntactic errors students made, before and after the intervention. The results of the pretest are presented in Table 1.

Table 1: Results of the Pre-Test in percentages, according to each type of error

\begin{tabular}{|l|c|c|c|c|c|}
\hline \multicolumn{1}{|c|}{ Description } & Word Order & Negation & Pluralization & Subject Omission & TOTAL \\
\hline Errors & $57 \%$ & $58 \%$ & $64 \%$ & $55 \%$ & $59 \%$ \\
\hline Correct answers & $43 \%$ & $42 \%$ & $36 \%$ & $45 \%$ & $41 \%$ \\
\hline Total & $\mathbf{1 0 0 \%}$ & $\mathbf{1 0 0 \%}$ & $\mathbf{1 0 0 \%}$ & $\mathbf{1 0 0 \%}$ & $\mathbf{1 0 0 \%}$ \\
\hline
\end{tabular}

According to the results of the pretest, the most prevalent error is Pluralization with $64 \%$, followed by Negation with 58\%, then by Word Order with $67 \%$, and finally by Subject Omission with $55 \%$ out of $100 \%$. These results are similar to those obtained in the study carried out by Kestern and Gorman (2008) and Coello and Coello (2009); they considered that these errors might be caused by the Spanish cues that native speakers transfer into English.

On the other hand, the results of the post-test, after the intervention, present some differences as it can be seen in Table 2 .

Table 2: Results of the Post-Test in percentages, according to each type of error

\begin{tabular}{|l|c|c|c|c|c|}
\hline \multicolumn{1}{|c|}{ Description } & Word Order & Negation & Pluralization & Subject Omission & TOTAL \\
\hline Errors & $48 \%$ & $42 \%$ & $29 \%$ & $47 \%$ & $42 \%$ \\
\hline Correct answers & $52 \%$ & $58 \%$ & $71 \%$ & $53 \%$ & $58 \%$ \\
\hline TOTAL & $\mathbf{1 0 0 \%}$ & $\mathbf{1 0 0 \%}$ & $\mathbf{1 0 0 \%}$ & $\mathbf{1 0 0 \%}$ & $\mathbf{1 0 0 \%}$ \\
\hline
\end{tabular}

By comparing the results in Table 1 and 2, it is clear that the intervention yielded favorable results. In the post test, the most prevalent error is Word Order with $48 \%$, followed by Subject Omission with 47 $\%$, Negation with $42 \%$, and Pluralization with $29 \%$ out of $100 \%$. These results are below $50 \%$, which is considerably different from the pre-test, in which the errors are over 50\%. Additionally, according to the post- test analysis, seven $(21.88 \%)$ students out of the 32 did not make any errors in pluralization. This fact also shows that the strategies used in the intervention to overcome the errors worked favorably. 
The questionnaires for both teachers and students were semi-structured. In the questionnaire for students, four questions were related to morphosyntactic errors, and in the teachers' questionnaire, one question addressed specifically the four errors. The results concerning the morphosyntactic errors made by the students are reflected in Tables 3 and 4.

Table 3: Dominant Morphosyntactic Errors - Student responses

\begin{tabular}{|l|c|c|c|c|c|}
\hline \multicolumn{1}{|c|}{ Description } & Word Order & Negation & Pluralization & Subject Omission & TOTAL \\
\hline Errors & $35.94 \%$ & $75.00 \%$ & $44.53 \%$ & $37.50 \%$ & $47.73 \%$ \\
\hline Correct answers & $64.06 \%$ & $25 \%$ & $55.47 \%$ & $62.50 \%$ & $51.75 \%$ \\
\hline TOTAL & $\mathbf{1 0 0 \%}$ & $\mathbf{1 0 0 \%}$ & $\mathbf{1 0 0 \%}$ & $\mathbf{1 0 0 \%}$ & $\mathbf{1 0 0 \%}$ \\
\hline
\end{tabular}

The results presented in Table 3 show that the dominant morphosyntactic errors based on the students' responses to the questionnaire are different in comparison to the ones in the pre and post-tests. This might be because in the students' questionnaire, each morphosyntactic error appears just as a short sample, which might not be enough to determine the most and the least prevalent morphosyntactic errors.

On the other hand, in the teachers' questionnaire, there is one item related to morphosyntactic errors. The results vary again since teachers answered this item according to their experience; for example, the majority of teachers think that word order is the most prevalent syntactic error, followed by subject omission, negation, and pluralization. The results are presented in Table 4.

Table 4: Relative Frequency of Morphosyntactic Errors- Teacher responses

\begin{tabular}{|l|c|c|c|c|}
\hline$\%$ of students & Word Order & Subject Omission & Negation & Pluralization \\
\hline A. $0-25 \%$ & $7.69 \%$ & $23.08 \%$ & $7.69 \%$ & $7.69 \%$ \\
\hline B. $26-50 \%$ & $38.46 \%$ & $53.85 \%$ & $53.85 \%$ & $46.15 \%$ \\
\hline C. $51-75 \%$ & $53.85 \%$ & $15.38 \%$ & $38.46 \%$ & $46.15 \%$ \\
\hline D. $76-100 \%$ & $0.00 \%$ & $7.69 \%$ & $0.00 \%$ & $0.00 \%$ \\
\hline
\end{tabular}

\subsection{IMPACT PRODUCED ON THE STUDENTS DURING THE INTERVENTION}

The impact produced by the intervention was measured not only through the results obtained from pre and post- tests, but also by applying the statistical test Paired T test. This test calculates the difference between the pre- and post-test and helps to identify if the difference is statistically significant or not (Tamayo, $\mathrm{n} / \mathrm{d}$ ). In addition, to show the significance of the intervention on the four morphosyntactic errors under study, the analysis was done through the statistical program IBM SPSS statistics. According to the statistical results obtained from the pre and post- tests, the intervention carried out by the teacher had a positive and significant impact on the students' learning process to overcome certain errors. Thus, in the case of word order, the average rating of this error increased from 3.45 to 4.07. Similarly, regarding the negation error, the average rating went from 3.48 to 4.55 , and on the Pluralization error, the average rating increased from 2.93 to 5.59 . 
On the contrary, the impact on subject omission was not too significant because there is only a slight difference; however, the average rating increased from 3.52 to 4.14 . This does not necessarily mean that the teacher did not sufficiently reinforce how to overcome this error; it could also have to do with the students' performance.

\subsection{FACTORS THAT INDUCE HIGH SCHOOL STUDENTS TO MAKE MORPHOSYNTACTIC ERRORS}

One of the objectives of this paper was to identify possible factors that induce Spanish high school students to make some morphosyntactic errors, such as the ones under study. Indeed, the errors under analysis in this research are considered as dependent variables because they depend on different circumstances presented during the learning process. According to the students' answers and the quantitative analyses, the errors depend on some independent variables or factors, such as: age, extra English courses, tasks done at home, and dictionary use. In this context, to determine the most prevalent independent variables that make students have morphosyntactic errors, a program called IBM SPSS statistics 21 was used. This program used a model called ANOVA.

In accordance with the final results of ANOVA, the coefficients that determine the independent variables as the main case of the morphosyntactic errors are represented in Table 5.

Table 5: Modelo RML of Morphosyntactic errors- Coefficients ${ }^{\text {a }}$

\begin{tabular}{|c|c|c|c|c|c|c|}
\hline & \multirow[t]{2}{*}{ Model } & \multicolumn{2}{|c|}{ Non-standardized coefficients } & $\begin{array}{c}\text { Typified } \\
\text { coefficients }\end{array}$ & \multirow[t]{2}{*}{$\mathrm{T}$} & \multirow[t]{2}{*}{ Sig. } \\
\hline & & $\mathrm{B}$ & T. Error & Beta & & \\
\hline \multirow{6}{*}{1} & (Constant) & -33.129 & 35.309 & & -.938 & .358 \\
\hline & Courses & .560 & 6.036 & .068 & .093 & .927 \\
\hline & $\mathrm{N}^{\circ}$ of courses & -.560 & 3.576 & -.108 & -.157 & .877 \\
\hline & Tasks & -2.704 & 1.232 & -.393 & -2.194 & .039 \\
\hline & Dictionary & 1.086 & .628 & .340 & 1.729 & .098 \\
\hline & Age & 2.354 & 2.046 & .285 & 1.150 & .262 \\
\hline \multirow{5}{*}{2} & (Constant) & -35.319 & 25.684 & & -1.375 & .182 \\
\hline & $\mathrm{N}^{\circ}$ of courses & -.242 & 1.008 & -.047 & -.240 & .812 \\
\hline & Tasks & -2.704 & 1.206 & -.393 & -2.243 & .035 \\
\hline & Dictionary & 1.095 & .608 & .343 & 1.801 & .085 \\
\hline & Age & 2.481 & 1.484 & .300 & 1.672 & .108 \\
\hline \multirow{4}{*}{3} & (Constant) & -34.100 & 24.679 & & -1.382 & .180 \\
\hline & Tasks & -2.700 & 1.182 & -.393 & -2.285 & .031 \\
\hline & Dictionary & 1.150 & .552 & .360 & 2.083 & .048 \\
\hline & Age & 2.400 & 1.416 & .291 & 1.695 & .103 \\
\hline \multirow{3}{*}{4} & (Constant) & 7.482 & 2.729 & & 2.742 & .011 \\
\hline & Tasks & -2.848 & 1.222 & -.414 & -2.331 & .028 \\
\hline & Dictionary & 1.023 & .567 & .320 & 1.804 & .083 \\
\hline
\end{tabular}

If each model is observed, especially model four, the variables that have less significance in improving the English language are tasks and dictionaries. In other terms, students have an average of 
morphosyntactic errors of 7.48 out of 8 . In the case of tasks, the morphosyntactic errors might be reduced to 2.84 if students do more tasks at home. Similarly, when students use the dictionary too much, they tend not to reduce errors; on the contrary, they tend to increase errors at least 1.02 . This might be because they probably think all the time in their L1 instead of the L2. It is important to note that the results obtained are according to the students' questionnaire. Additionally, the other independent variables, such as age, course, and number of courses, according to the ANOVA model, present a low percentage of influence, not at the same range as the ones described before.

\subsection{QUALITATIVE STUDY}

The results, related to the factors that influence the production of morphosyntactic errors, obtained from the questionnaires applied to the 32 students and 13 English teachers are presented in this section. The questionnaires were designed to know why students make morphosyntactic errors like the ones in this study.

One of the factors that influences whether learners continue making morphosyntactic errors is age. In effect, the study was applied to students between 16 - 20 years old and even when the statistical analyses showed no significance, they revealed that age is important in the English learning process as well. Thus, the older a learner is, more morphosyntactic errors are prevalent in him or her. These results are supported by those obtained by Khalifa (2012). Indeed, this author states that people who study another language from an early age tend to have a high proficiency when they are adults, especially in the case of morphosyntax.

When we mention that a learner should learn another language from a young age, it means high experience in the language. However, this is not enough. According to the second question in the students' questionnaire, which refers to extra English classes, the results indicate that in order to have less morphosyntactic errors, students should be more in touch with the language; for instance, some students who had good results used to take extra English classes outside the high school environment. In the same vein, another possible factor to avoid morphosyntactic errors is the frequency of doing English activities at home. Thus, the more a student practices the English language, the more he would become fluent and make fewer errors. Again, this is confirmed by both the students' answers and the statistical analysis carried out in the quantitative section.

Another factor, which surprisingly does not help students avoid morphosyntactic errors, is the use of a dictionary. According to the statistical analysis, many teachers and students believe that a dictionary helps to improve English. This might be the case, but likely just to improve vocabulary. In this context, based on the authors' experience, a Spanish-English or English- Spanish dictionary might be a distraction 
when producing written texts in English since students use the dictionary only to translate words without focusing on sentence structure.

Finally, the students wrote a journal each week about their thoughts and activities done during the intervention; they expressed that doing tasks and activities proposed by the teacher are really important and motivating. Certainly, some students who received a high score in the post-test were actually motivated to learn English; some of them were even studying English at private language institutes, as mentioned earlier. On the other hand, students who received a low score in the post-test expressed that they did not like English, and the activities and the methodology proposed by the teacher were not good for them. In consequence, based on these results, it is important to be more in touch with the language and motivated to learn another language to avoid morphosyntax errors.

Regarding teachers' responses about what skill they focus more on in classes, most of the teachers mentioned that the skills they usually focused more on were speaking and reading, but listening and writing were practiced with less frequency. Table 6 illustrates this data.

Table 6: Relative Frequency of the Teachers' focus on each language skill Teacher's response

\begin{tabular}{|c|l|l|}
\hline Preferred Skill & Frequency & $\%$ \\
\hline Speaking & 6 & $46.15 \%$ \\
\hline Reading & 4 & $30.77 \%$ \\
\hline Listening & 1 & $7.69 \%$ \\
\hline Writing & 2 & $15.38 \%$ \\
\hline Total & $\mathbf{1 3}$ & $\mathbf{1}$ \\
\hline
\end{tabular}

It is worth mentioning that the results from the analysis of teachers' questionnaires indicate that there are some possible reasons why students do not correct their morphosyntactic errors in writing such as the fact that teachers do not spend enough time on practicing this skill, or they do not provide sufficient feedback.

In addition, it is important to mention that teachers use different strategies to correct morphosyntax errors. Table 7 presents these strategies mentioned in the teacher's questionnaire. 
Table 7: Common Strategies used by teachers to correct morphosyntax errors

\begin{tabular}{|l|c|}
\hline \multicolumn{1}{|c|}{ Strategy } & Frequency \\
\hline Feedback & 3 \\
\hline Dictation & 2 \\
\hline Self - Correction & 2 \\
\hline Error correction & 1 \\
\hline Exercises for correcting mistakes & 1 \\
\hline Grammar exercises & 1 \\
\hline More Practice & 1 \\
\hline Pair correction & 1 \\
\hline Plural Exercises & 1 \\
\hline Reading Strategy & 1 \\
\hline Rewriting strategy & 1 \\
\hline Role plays & 1 \\
\hline Teach Grammatical Rules & 1 \\
\hline Unscrambling & 1 \\
\hline Watching videos & 1 \\
\hline Word Order exercises & 1 \\
\hline
\end{tabular}

\section{CONCLUSIONS}

Based on the theoretical framework presented previously and other studies regarding morphosyntactic errors, and the intervention carried out with 32 students of a public high school in Cuenca, Ecuador, we can conclude that L1 interference on the L2 has both positive and negative effects.

In the case of the positive effects, Spanish speakers learning English use some similar morphological patterns that exist in both languages. In this case, cognates and some word endings are really important since these facilitate the learning of the L2 by Spanish high school students. Regarding negative transfer, most of the students tend to transfer the L1's morphology and syntax to the L2, which induces them to make morphosyntactic errors in writing.

Regarding the first question of this study, "What are the most common English morphosyntactic errors produced by high school students in writing?" four errors were determined as the most common: word order, pluralization, negation, and subject omission. Unfortunately, in many cases, teachers do not pay too much attention to these morphosyntactic errors. In this case, we might say that the intervention carried out by the students in this research had a positive effect because these errors were corrected and reduced from $59 \%$ in the pre-test to $42 \%$ in the post-test.

Concerning the second question, "What are the factors that induce students to make these errors?," it was determined that morphosyntactic errors occurred due to linguistic transfer or cross linguistic influence; however, there were also other factors such as lack of motivation, and the use of dictionaries. In effect, students are not always motivated to learn English, and the constant use of dictionaries is considered a distraction to language learning because students rely on translation and not on their knowledge of the L2. In this context, students tend to translate a text word for word, but they forget that the morphosyntax of English is different. 
Another factor that might induce students to continue making morphosyntactic errors is the lack of practice of the writing skill. According to the results of the teacher's questionnaire, teachers concentrate more on the reading and speaking skills, but not too much on the writing and listening skills; thus, it does not help students to avoid morphosyntactic errors since they do not receive enough practice and feedback on the writing skill.

As an answer to question three, "What kinds of activities can help high school students avoid the interference of Spanish morphosyntax in English?," we can affirm that English teachers should focus more on morphosyntactic error correction by applying self-correction, feedback, and dictation as the main activities to overcome the problem presented in this study. Moreover, we also propose that the number of English hours in the third year of Bachillerato (last year of secondary education) be more than three hours per week. This would provide students with more contact with the language. Additionally, the curriculum for the two previous school years should include morphosyntax correction. Finally, based on the results obtained in this research, it is suggested that further studies about other morphosyntactic errors are undertaken in order to improve students' writing skills. 


\section{REFERENCES}

Campos, G. (2011). Acquisition of Morphosyntax in the Adult Second Language: The Phonology Factor [Doctorate thesis, University of Iowa]. The University of Iowa Institutional Repository. https://ir.uiowa.edu/etd/2677/

Coello, R., \& Coello, F. (2009). Native Language Interference in Learning English as a Foreign Language: an Analysis of Written Material Produced by Spanish Speaking Students in Senior High School Classes [Bachelor's Thesis, Universidad Técnica Particular de Loja]. https://1library.co/document/4yr4xoqo-interference-learningenglish-language-analysis-material-speaking-students.html

Cresswell, J., \& Garrett, A. (2008). The "movement" of mixed methods research and the role of educators. South $\begin{array}{lllll}\text { African } & \text { Journal } & \text { Education. } & 28 . & 321-333 .\end{array}$ http://www.sajournalofeducation.co.za/index.php/saje/article/view/176/114

Heydari, P., \& Bagheri, M. S. (2012). Error Analysis: Sources of L2 Learners' Errors. Theory and Practice in Language Studies, 2(8), 1583-1589. http://www.academypublication.com/issues/past/tpls/vol02/08/06.pdf

Isakson, C. \& Spyridakis, J. (2003). The Influence of Semantics and Syntax on What Readers Remember. Technical Communication, $\quad 50$, 538-553. https://www.hcde.washington.edu/files/people/docs/Isakson_Spyridakis_Sem_Syn.pdf

Jarvis, S. \& Pavlenko, A. (2008). Crosslinguistic Influence in Language and Cognition. Taylor \& Francis e-library. https://books.google.com.ec/books?hl=es\&lr=\&id=kniRAgAAQBAJ\&oi=fnd\&pg=PP1\&dq=language+transfer+ or+crosslinguistic+influence\&ots $=\mathrm{gcPCg} 2 \mathrm{IOOJ} \& \mathrm{sig}=\mathrm{X} 14 \mathrm{OVn}$-sxEfGdw-

A0NGJxgkyTQ8\&redir_esc=y\#v=onepage \& $\mathrm{q}=$ language $\% 20$ transfer $\% 20$ or $\% 20$ crosslinguistic $\% 20$ influence $\& \mathrm{f}=\mathrm{f}$ alse

Kester, E., \& Gorman, B. (2008). Spanish-influenced English: Typical Semantic and Syntactic Patterns of the English Language Learner. Bilinguistics. https://bilinguistics.com/wp-content/uploads/2013/04/TypicalSemantics-and-Syntax-in-the-English-Language-Learner-CEU.pdf

Khalifa, E. (2012). The Effects of Age Factor on Learning English: A Case Study of Learning English Granada in Saudi Schools, Saudi Arabia. English Language Teaching, 5(1), 127-139. https://files.eric.ed.gov/fulltext/EJ1078726.pdf

Kthupi, E. (2015). Errors in the Foreign Language Learning Process. Interdisciplinary Journal of Research and Development, 2(1), 97-100. https://www.uamd.edu.al/new/wp-content/uploads/2015/11/17.Ermira-Kupthi.pdf

Lapo, R. (2008). Facilitation of Positive Transfer from Spanish to English: Analysis of Similarities and Differences in Regards to Semantics, Syntax, and Phonology. Academics, 8(5) 1- 8. http://docplayer.net/21429954-Semanticssyntax-and-phonology-by-rachel-lapo.htmlhttp://docplayer.net/21429954-Semantics-syntax-and-phonology-byrachel-lapo.html

Lieber, R. (2009). Introducing Morphology. Cambridge University Press.

Luna, R. (2010). Interlanguage in Undergraduates' Academic English: Preliminary Results from Written Script Analysis. Encuentro, 19, 60-73. https://core.ac.uk/download/pdf/58908947.pdf

Martínez, A. (2011). Estrategias Docentes para el Aprendizaje del Idioma Inglés como Segunda Lengua en la Educación Primaria [Bachelor's Thesis, Universidad Pedagógica Nacional]. http://200.23.113.51/pdf/27906.

Minkkinen, T. (2015). The Influence of Morphological Congruency on the Acquisition of the English Plural Morpheme -s. A corpus study on Japanese and Spanish learner corpora [Master' Thesis, University of Eastern Finland]. http://urn.fi/urn:nbn:fi:uef-20151226 
Mujsinovic, J. (2015). The analysis of subjects in the oral and written production of L2 English learners: transfer $\begin{array}{lllll}\text { and language } & \text { Sypology. }\end{array}$ https://reader.elsevier.com/reader/sd/pii/S1877042815044547?token=81A4BCDE5C3C3BDBFAA08E6C7CDF7 0C5FE3054576AE3AFE4379496AB48484B849B030272D166B38D614D7F0633DA4C39\&originRegion=useast-1\&originCreation $=20210520225041$

Sanchez, R. (2015, June). Syntactic Mismatches between English and Spanish: A Descriptive Analysis and Classification. $\quad$ Estudis $\quad d$ "Anglès $i \quad$ Clàssiques. https://ddd.uab.cat/pub/tfg/2015/141238/TFG_raquelsanchez.pdf

Sells, P., \& Kim, J. (2008). English Syntax: An Introduction. CSLI publications. https://carrerainglesuce.files.wordpress.com/2019/05/syntax.pdf

Shepherd, A. (2011). Want to talk about it? A Minimalist analysis of subject omission in colloquial English [Master's Dissertation, University of Southampton]. University of Southampton Repository. https://www.academia.edu/1991772/Want_to_talk_about_it_A_Minimalist_analysis_of_subject_omission_in_col loquial_English

Souriyavongsa, T., Rany, S., Jafre, M., \& Lai, L. (2013). Factors Causes Students Low English Language Learning: A Case Study in the National University of Laos. International Journal of English Language Education, 1(1), 179192. https://doi:10.5296/ijele.v1i1.3100

Tarone, E. (2006). The Interlanguage Hypothesis. Elsevier, 5(1), 747- 752. http://socling.genlingnw.ru/files/ya/interlanguage\%20Tarone.PDF

Taboada, M. (1995). Theme markedness in English and Spanish: A Systemic-Functional Approach [Master's Thesis, Complutense University of Madrid]. https://www.sfu.ca/ mtaboada/docs/publications/taboada-thememarkedness.pdf

Tamayo, I. (s.f.). Contraste de una y dos medias: PRUEBAS t. http://www.ugr.es/ imartin/TEMA5_3P.pdf

Van Valin, R. (2001). An Introduction to syntax. Cambridge University Press. https://vulms.vu.edu.pk/Courses/ENG509/Downloads/[Robert_D._van_Valin_Jr]_An_Introduction_to_Synta(B ookZZ.org).pdf

William, T. (2003). A Study of Native Spanish Speakers' Writing in English for Teachers. Inquiry, 8(1), 1-8. http://files.eric.ed.gov/fulltext/EJ876837.pdf

Xiangui, Zh. (2005). Learning Theories and Second Language Learning. CELEA journal, 28(5), 120-127. Retrieved from http://www.celea.org.cn/teic/63/63-120.pdf.

Yule, G. (2010). The Study of Language. 4th ed. New York, U.S.A. Cambridge University Press.

Zamora, V. (2015). Comparative Study of the Use of Double Negatives by Native English Speakers and Spanish Learners of English [Master's Thesis, University of Valladolid]. Repositorio Documental - Universidad de Valladolid. https://uvadoc.uva.es/handle/10324/17575 